Article

\title{
Gene Editing for Improved Animal Welfare and Production Traits in Cattle: Will This Technology Be Embraced or Rejected by the Public?
}

\author{
Maria Cristina Yunes ${ }^{1}\left(\mathbb{D}\right.$, Zimbábwe Osório-Santos ${ }^{1}\left(\mathbb{D}\right.$, Marina A. G. von Keyserlingk ${ }^{2} \mathbb{D}$ \\ and Maria José Hötzel ${ }^{1, * \mathbb{D}}$ \\ 1 Laboratório de Etologia Aplicada e Bem-Estar Animal, Departamento de Zootecnia e Desenvolvimento Rural, \\ Universidade Federal de Santa Catarina, Florianópolis 88034-001, Brazil; mcyunes@hotmail.com (M.C.Y.); \\ zbwe_@hotmail.com (Z.O.-S.) \\ 2 Animal Welfare Program, Faculty of Land and Food Systems, The University of British Columbia, \\ Vancouver, BC V6T 1Z4, Canada; nina@mail.ubc.ca \\ * Correspondence: maria.j.hotzel@ufsc.br
}

Citation: Yunes, M.C.; Osório-Santos, Z.; von Keyserlingk, M.A.G.; Hötzel, M.J. Gene Editing for Improved Animal Welfare and Production Traits in Cattle: Will This Technology Be Embraced or Rejected by the Public? Sustainability 2021, 13, 4966.

https://doi.org/10.3390/su13094966

Academic Editor: Gerhart U. Ryffel

Received: 31 March 2021

Accepted: 25 April 2021

Published: 28 April 2021

Publisher's Note: MDPI stays neutral with regard to jurisdictional claims in published maps and institutional affiliations.

Copyright: (c) 2021 by the authors. Licensee MDPI, Basel, Switzerland. This article is an open access article distributed under the terms and conditions of the Creative Commons Attribution (CC BY) license (https:// creativecommons.org/licenses/by/ $4.0 /)$.

\begin{abstract}
Integrating technology into agricultural systems has gained considerable traction, particularly over the last half century. Agricultural systems that incorporate the public's concerns regarding farm animal welfare are more likely to be socially accepted in the long term, a key but often forgotten component of sustainability. Gene editing is a tool that has received considerable attention in the last five years, given its potential capacity to improve farm animal health, welfare, and production efficiency. This study aimed to explore the attitudes of Brazilian citizens regarding the applications of gene editing in cattle that generate offspring without horns; are more resistant to heat; and have increased muscle tissue. Using a mixed-methods approach, we surveyed participants via face-to-face, using in-depth interviews (Study 1) and an online questionnaire containing closed-ended questions (Study 2). Overall, the acceptability of gene editing was low and in cases where support was given it was highly dependent on the type and purpose of the application proposed. Using gene editing to improve muscle tissue growth was viewed as less acceptable compared to using gene editing to reduce heat stress or to produce hornless cattle. Support declined when the application was perceived to harm animal welfare, to be profit motivated or to reinforce the status quo of intensive livestock systems. The acceptability of gene editing was reduced when perceptions of risks and benefits were viewed as unevenly or unfairly distributed among consumers, corporations, different types of farmers, and the animals. Interviewees did not consider gene editing a "natural" process, citing dissenting reasons such as the high degree of human interference and the acceleration of natural processes. Our findings raised several issues that may need to be addressed for gene editing to comply with the social pillar of sustainable agriculture.
\end{abstract}

Keywords: bioethics; cattle; genetic modification; naturalness; public attitudes

\section{Introduction}

The concept of sustainability takes into account economic, environmental and social aspects [1,2]. However, historically the social pillar has received less attention, likely due to it including moral values, making it conceptually difficult to quantify. The interactions between the different stakeholders, animal production practices and concerns about animal welfare are complex and must be included in discussions when striving for sustainability. Thus, integrating social sustainability into discussions concerning agri-food systems should include all perspectives of the different sectors involved in livestock systems, as well as citizens' and consumers' opinion, as only then can socially sustainable solutions be identified. Failure to include the end users of products of food animal agriculture can result in consumer demands being expressed in ways (i.e., the legislative sphere) without taking 
into account the needs of producers or the animals [3]. Approaches such as this can cause great damage to certain segments of the animal production sector, especially small-scale producers who may have difficulty adapting to abrupt external demands.

The industrialization of agriculture, frequently justified by the pressure to feed a growing population, has been argued to have come at the expense of the quality of life of farm animals [4]. In addition, it has come at the expense of an ever-growing distance between agri-food systems and consumers. Most urban citizens are unaware of the practices adopted in animal production and have little knowledge as to the numbers of farm animals housed in intensive systems; however, once informed many reject them [5]. Similar responses by members of the public have been shown in Brazil (e.g., [6,7]). Many "uninformed" stakeholders associate outdoor systems with improved animal welfare and product quality [8-11]. Thus, the sustainability of production sectors may be challenged if citizens begin to actively oppose current farm husbandry practices.

The recent discovery of gene editing, a controlled change in the DNA of a living organism, opens the possibility of solving issues related to animal production [12]. Gene editing proponents promise solutions for animal health and welfare problems facing the livestock industries [13,14]. For cattle, the painful process of disbudding could be rendered unnecessary by inserting into its genome the polled gene, which is natural but not frequent in the Holstein breed [15]. Inserting the heat tolerance gene (SLICK) commonly found in Senepol cattle into the genome of Holstein cattle could help increase the thermoregulatory ability of this widely used dairy breed $[16,17]$. The insertion of the gene responsible for the double-muscle phenotype in cattle could potentially increase meat production, while at the same time potentially improving calving ease in double muscling breeds [18,19].

Among the main advantages cited for gene editing over conventional genetic selection is the possibility of modifying only the characteristics of interest in a much shorter intergenerational interval than natural selection, while allowing for desired traits to be phenotypically expressed [20]. Despite these potential benefits, some argue that caution is needed regarding the safety of the technique [21,22]. Other ethical concerns raised relate to issues regarding environmental sustainability, human health, animal welfare, as well as potential social and economic implications, including how the benefits of the technology will be distributed and how this technology may impact producers [19,23,24]. When asked, the public appears to base their assessment of this technology on judgments about the end use of the specific application of genetic modification $[25,26]$. In general, people show less support for agricultural uses of genetic modification technologies $[27,28]$, less support for application to animals than to plants and microorganisms [29-31], and less support for applications that are associated with production benefits than animal welfare benefits [26].

Unlike other technologies, gene editing has the ability to make rapid changes within the genome. Therefore, public trust may be eroded, thereby undermining the social sustainability of the associated industry if negative effects are identified or if no concrete improvement in the welfare of animals is delivered. In general, the public is more critical of new food technologies when benefits are not clearly perceived, likely reflecting perceived risks and moral concerns [27]. In contrast, when technologies are perceived as useful and morally acceptable, the public may discount risk [32,33]. It follows that when technological novelties are introduced to the market, personal decisions may be highly influenced by trust in social institutions, including scientists, industry and governmental institutions $[34,35]$. The current challenge facing the use of gene editing in food production is not only finding applicable novel agricultural practices and technologies, but also finding improved ways to engage in dialogue with society. Ideally, the introduction of novel gene editing technologies into society is performed in a way that allows thoughtful consideration, informed decisionmaking and trustworthiness on the part of all key actors.

Brazilians are optimistic about technologies [36], including those related with agriculture [7,31] and food production [37]. A previous survey concluded that, although animal welfare benefits arising from gene editing were predictors of support, perceived risks and uncertainty may be more determinant of Brazilian public attitudes towards gene editing 
of farm animals [29]. Here, we were interested in the public perception of gene editing technology when used in cattle; specifically how individuals weigh the risks in view of potential benefits for animal welfare, production and the environment. Given this scenario, two studies were conducted, using three examples of gene editing applications in cattle: hornlessness, improved heat resistance or improved muscle growth. The first was a qualitative study based on face-to-face in-depth interviews, aimed at exploring citizens' attitudes regarding the use of gene editing to improve animal production or welfare in cattle (objective 1); the second study used an online questionnaire with closed-ended questions, aimed at assessing citizens' acceptability of the three applications and the influence of demographic characteristics (objective 2).

\section{Materials and Methods}

We used a mixed-methods approach to survey participants to address our objectives. Using face-to-face in-depth interviews (Study 1; Objective 1); and an online questionnaire containing closed questions (Study 2; Objective 2). In both studies the volunteer participants were at least 18 years old. Study 1 was approved by the Ethics Committee on Experimentation of Santa Catarina State University (P. 2.051.639). All procedures in Study 2 followed the ethical principles established by Regulations n. 466/2012 and 510/2016 from CNS, the Brazilian National Health Council, which stipulates that online surveys that do not identify participants are exempted from evaluation by Ethic Committees. Before answering the questionnaire, participants had to read an informed consent statement and accept the conditions of the study, i.e., that participation was voluntary, only people older than 18-years old could participate, that participation was anonymous, that data would be used exclusively for the purposes of scientific research, and that participants had the opportunity to withdraw at any moment by not returning the form. All participants were required to give consent about their participation (by signing a consent form in the face-toface interviews or clicking a yes button on the online survey) before taking the survey. After agreeing to participate all participants in both Study 1 and 2 were first asked to provide socio-demographic information relating to sex, age, education, Brazilian geographic region of current residence, urban or rural area, their level of association with livestock production and food consumption patterns.

\subsection{Study 1}

Study 1 was conducted through structured interviews, which allowed the researcher to establish a dialogue with the participant based on a question guide designed to elicit responses on the theme proposed [38]. Participants were recruited during the 16th and 17th Teaching, Research and Extension Week, SEPEX, at the Federal University of Santa Catarina in Florianopolis, 19 to 21 October 2017 and 18 to 20 October 2018, respectively. The interviews were conducted in two waves: in 2017 we interviewed 18 participants, analysed the responses obtained and identified issues that needed to be further explored; therefore, in 2018 we conducted another 14 interviews. Following the second data analysis it was determined that no new elements were identified and so it was concluded that the number of interviews provided good data saturation, i.e., provided an in-depth, diverse and rich account of the topic.

SEPEX's visitors were approached by students and invited to participate voluntarily in a scientific study. During recruitment self-selection bias was minimized by initially asking potential participants if they would like to participate in a survey about animal production, with no further specification of the nature of the study. Participants were then accommodated in front of a computer where the researcher (MCY) introduced the survey through a brief PowerPoint presentation with 18 slides (Supplement 1). The first 14 slides introduced the gene editing technology and the three examples (hornessless, heat resistance and double-muscle) with some details on the gene editing technique and the current animal welfare concerns that led to the belief that the gene editing technology would provide a viable solution. The last 4 slides provided a list of questions where the 
researcher encouraged participants to discuss their views about: (1) potential benefits and risks to society, producers and to animals; (2) whether gene editing using genes found in the species should be considered a genetic modification or could be considered natural; (3) if they considered any of the gene editing applications more/less acceptable and why; and (4) who they trusted regarding information on these topics. During the explanation participants asked questions, made comments and expressed opinions. Only when the topics listed in the script were not covered by the participant, the interviewer covered the issue.

\section{Data Analysis}

All interviews, which lasted $14 \mathrm{~min}$ on average (from 8 to $20 \mathrm{~min}$ ), were conducted in Portuguese, recorded and transcribed verbatim by MCY, ZOS, and verified by MJH. To analyse data we used an inductive (reflexive) thematic analysis that essentially works "bottom-up" $[39,40]$. The findings are thus grounded in the interviewees' responses. Transcripts were read exhaustively for familiarization with the data and discussed among MCY, ZOS and MJH. These authors coded a subset of the transcripts independently, discussing their findings until reaching agreement. Then, new transcripts were coded and this process repeated in an iterative way until agreement was reached. Codes were then developed into themes, which were again discussed among all authors and refined. After this, titles and definitions for each theme were generated. Extracts that best represented the themes were selected and translated to English by MJH and MCY and meaning verified with MvK.

\subsection{Study 2}

The online questionnaire (Supplement 2) was conducted using the Google forms platform. Recruitment of participants was conducted using the social media Instagram. An advertisement (in Portuguese) saying "We want to hear from you. Access the link to collaborate with our research on the relationship between people and animals" was posted inviting the public to participate in the survey, without further information on the survey subject. The Instagram account was created exclusively to share the questionnaire and had no information on the identity of the authors or the research group. We strategically targeted participants to match the age and gender distribution of the Brazilian population [41]. The questionnaire was initially pilot tested using 20 randomly recruited participants; their responses were used to refine the questions prior to release.

To introduce the issue, genetic modification was defined as "the process of using biotechnology to alter an organism's genetic information (DNA) to produce a certain characteristic". Next, the participant was asked how much he/she had heard or w and how much he/she had heard or read about gene editing of plants, animals or humans. The participant was then presented a text about the following three examples of gene editing in dairy cows: hornlessness (POLLED), improved heat resistance (HR) or improved muscle growth (MG).

The Belgian Blue bovine breed has a gene that allows muscle growth approximately $20 \%$ greater than the breeds generally used in our production systems. A possible alternative to increase meat production in Brazil, maintaining other characteristics of meat quality, is to insert this gene in the desired breeds. Do you consider genetic modification of cattle to produce more meat ... [image of a Belgian Blue cattle].

In Brazil, most dairy cows are raised on pasture, and in many cases have little or no access to shade. Dairy breeds have little resistance to heat and suffer from thermal stress. A possible alternative is to genetically modify cattle so that it has characteristics that give it greater resistance to heat. This method consists of integrating the 'slick' gene (found in some cattle breeds) in the genome of dairy breeds. As a result, all calves are born more resistant to heat. Do you consider genetic modification of cattle to make them more resistant to heat... [image of dairy cows at pasture in the shadow]. 
In Brazil, almost all dairy cows have their horns removed when they are young by burning or cutting the cornual tissue. Removing the horns is painful and medication is generally not used to minimize pain. A possible alternative is to genetically modify cattle so that the horn never grows. This method consists of integrating a 'hornless' gene (found in some cattle breeds) into the genome of dairy breeds; as a result, all calves are born hornless. Do you consider genetic modification of cattle so that they do not have horns ... . [image of one horned and one hornless adult cows]. After each example (the order of the three texts was randomized), the participant was asked to rate the acceptability of the application, on a Likert scale ranging from 1 (not at all acceptable) to 5 (totally acceptable). Participants were then asked to assess the risk and benefits of gene editing in cattle, on a Likert scale ranging from 1 (none) to 5 (very high).

\section{Statistical Analysis}

In Study 2, 864 responses were obtained; 277, 299 and 288 were presented first the application to genetically modify cattle to be hornless, improve heat resistance or muscle growth example, respectively. Participants' acceptability of the three different applications was compared using the Wilcoxon test. Responses regarding acceptability were grouped ( 1 and 2 = not acceptable, $3=$ intermediate, and 4 and $5=$ acceptable) for descriptive purposes. To test for associations between order of presentation or demographic variables and acceptability of each application, Kruskal-Wallis tests were used, with pairwise comparisons undertaken using Dunn's procedure utilizing a Bonferroni correction for multiple comparisons. Differences among groups with $p<0.001$ were accepted as representing significant differences; probability values lower than 0.001 were expressed as $p<0.001$. All the statistical analyses were performed with the R software (R Development Core Team, Vienna, Austria, 2011).

\section{Results}

\subsection{Study 1. Face-to-Face Interviews}

Demographics of interviewees are shown in Table 1. Distribution of sex and age approximately corresponded to the Brazilian population (IBGE, 2011). All participants resided in the southern region of Brazil, 97\% in urban areas. The majority (94\%) of interviewers had undergraduate education. Additionally, 22\% participants had grown up with some contact with farm animal production and 3\% had some professional involvement with agriculture.

Four themes were identified in the qualitative analysis as the most relevant concerns regarding gene editing of cattle: "Distribution of benefits and risks of gene editing of cattle", "Gene editing and the status quo in the food animal production systems", "Naturalness of gene editing and violations of the animals' integrity" and "Who is trustworthy when seeking information on gene editing?".

\subsubsection{Distribution of Benefits and Risks of Gene Editing of Cattle}

A salient concern among the interviewees was the potential down-stream implications of gene editing of cattle in regard to the animals, consumers, farmers, society, and the environment (e.g., P27 "I think that the studies are too recent to know if in the future there will be a consequence or not. So I think that, as a consumer, I prefer to consume meat that has no genetic improvement"; P31... because there are unidentified things, so it is not known if this can bring something... something bad, I don't know... Well, some kind of unknown effect, right?; P24-Actually, I'm not very much in favour of these things, you know? It seems like playing God. Like that, right? [explaining that there was no religious connotation in the analogy]... you make a change and you don't know how it will be passed on from here, I don't know, six generations ... ). 
Table 1. Study 1: Demographics of interview participants $(n=32)$, recruited during the 16th (2017) and 17th (2018) Teaching, Research and Extension Week at the Federal University of Santa Catarina in Florianopolis, Brazil.

\begin{tabular}{cc}
\hline Demographics & $\begin{array}{c}\text { Participants } \\
\boldsymbol{n} \mathbf{( \% )}\end{array}$ \\
Sex & \\
Male & $15(47)$ \\
Age & $17(53)$ \\
18 to 24 years old & \\
25 to 34 years old & $6(19)$ \\
35 to 44 years old & $11(34)$ \\
45 to 54 years old & $5(16)$ \\
55 years old and over & $6(19)$ \\
Education & $3(9)$ \\
Up to high school & $2(6)$ \\
Postgraduate & $15(50)$ \\
Current residence urban & $14(44)$ \\
Undergraduate education (complete or ongoing) & $31(97)$ \\
Not involved production & $24(75)$ \\
Grew up in an agricultural environment & $7(22)$ \\
Student (Agronomy) & $1(3)$ \\
\hline
\end{tabular}

All interviewees resided in Southern Brazil.

Many interviewees weighed the benefits for each of these independently, but some also considered which beneficiaries deserved precedence over others from an ethical perspective. In general, gene editing applications were considered more acceptable if they were perceived to reduce animal suffering and less acceptable if they were perceived to harm the animals (P19-“"In the case of the horn, the animal will not suffer as much and in the case of meat it will give more meat, but the animal will be suffering. You have to worry about that issue too, right? There is the question of excessive weight, you know, that the animal will suffer... With regard to heat, it is good, controlling this issue of heat for the animal is more complicated, so it's a good option. I think it will be a benefit for the animal... it will tolerate the heat more and will not suffer so much; P13 - I found the "hornless" one acceptable because it reduces the animal's suffering; P17-“... look, this last one [double musculature] I don't see any benefit, because the quality of life seems to me that it will be terribly reduced)". Some participants clearly stated that a premise for acceptability of gene editing of cattle was that the animals should benefit (P28- "I think that these genetic interventions should be done, but only when there are more benefits for the animal than for the farmer; P30-It's a difficult debate, because the ethical question, respect [for the fact] that it is an animal, [this] is a debate that has to be put into perspective. Mitigating animal suffering to compensate, eventually, production profit. I think you have to choose mitigation, for the welfare of the animal ... )".

The potential effects of the gene editing applications on consumers were very salient in the discussions. Many interviewees referred to this when voicing their opposition to the applications (P6-Does this modification of the gene cause any risk for us who are going to eat? This is a question I ask...; P15-If it is not healthy for the animal, it is not healthy for us) but also used similar reasons for justifying support (P29-The animal without a horn will not interfere with the condition, the milk... ). Another argument raised by the participants was that tampering with the animals' genetics for human profit has negative moral implications for society (P22 - It does damage to society, because we are becoming a more perverse society, increasing animal suffering for our profit. This can be considered a bad thing for society; P28Because [regarding] the risks, the problem is not knowing how to weigh them, not knowing when to stop. I think you can go on adding more and more things and creating little monsters that practically only serve humans and that's it. If society ends up forgetting that part, they [animals] will gradually 
be replaced, it is also bad. You lose that critical sense of how far to stop. . ; P21-But I don't know how far we need to exploit the animal in this way to obtain profits, do you understand?).

Many participants believed that producers would benefit from the gene editing technology (P30_... I mean, the logic is the economic logic, right? The biggest benefit is for the producer), although some made an exception for small producers (P24-For producers, there certainly are benefits... Because they will use less land... the family (farmer), on a small scale, maybe he won't have access to that; P22-... not every producer, because there are smaller producers, you know, unfortunately they don't have the benefits of profit, of progress, they work much more and have a much lower return ... ). However, some participants saw economic risks for producers (P8-I see risks for producers, because at first glance I see loss, because an animal like this is very expensive, and any failure will result in losses; P31_... for producers, too, there are risks, because they may be investing in a technology that in the end does not give them that return), with benefits only to large corporations (P30-I am not against genetic progress [I am a language scientist], but I think that humans have to have very clear ethical standards. The debate cannot be greed, rapid and growing profit cannot prevail, because the tendency is that large corporations end up dominating the production process. This is the tendency of both animal genetics and plant genetics. See the transgenics... ).

Gene editing was also referred to as a quick and less laborious way to overcome the problems of animal production, benefiting producers but at a great cost to the animals. In the view of these interviewees, farmers were seen to have a duty to take certain measures to avoid the need to modify the animals $(P 26-\ldots$ in reality, the main problem is that we want to change, without changing anything... Because, the one who changes, in this case through technology, is the animal....the problem is in the animal. ... all of these problems for which genetics is presented as a possible solution can be overcome in other ways; P23 - They don't want to plant a tree, they want to modify the cattle so that they can leave them in the heat, really. They do not want to plant a tree, so they make them [cattle] put up with the sun).

Some interviewees considered the collective harms and benefits resulting from the modification of the animals across the different players ( 4 - For producers... yes, they may have short, medium or long term risks. What if people start to get sick? What if the animals start to get sick?; P2-... there is benefit to animals and to society as well, because it generates more milk production, as well as economic increase for producers; P9_... this [referring to the double musculature phenotype] is good for the producer, it is good for society and good for the farmer [... ] I think that this cannot be abandoned, I think the benefit is very high; P27-I think the heat-resistant cattle could be something more acceptable. And [about] the hornless, I still have a certain doubt. But now the other type, which is the modification to increase the musculature, I don't see any benefit for the animal or for anyone). Finally, another issue considered by the interviewees was the distribution of benefits from gene editing among different groups of humans (P8-When they discovered the DNA code, I imagined that it would provide benefits. For example, when the person is 60 years old, he will have cancer so they get it, discover this DNA molecule and make a change. But this benefit is not reaching us, it is reaching very few people [...] preferentially the richest).

\subsubsection{Gene Editing and the Status Quo in the Food Animal Production Systems}

Mixed attitudes were expressed regarding the use of gene editing in cattle as a tool to improve animal welfare and production in intensive systems. A prevailing perception conveyed by many of the participants was that gene editing was being proposed to modify cattle when in fact other changes could be implemented to achieve the same goals. Many implied that they considered this move as negative, but inevitable.

A few interviewees praised the application of gene editing as a positive contribution towards the efficiency of animal production systems (P9-"... there must be pasture for cattle to eat, and pasture does not grow under the trees... I am pro-technology), or a welcomed tool for farmers' that did not use alternative measures, such as planting trees to provide shade or mitigating pain when disbudding the calves (P14 - "I think it's just an adaptation advantage. Because whether we want to or not, they will continue to bring Holstein cattle here, they will not 
stop. So, it is a way for you to try to improve the animal's welfare"; P23-[referring to POLLED] at least he didn't suffer from the dehorning... They will have to be without horns anyway, so it better be in a genetic way that doesn't hurt.). One interviewee expressed dissatisfaction with the production systems, conveying that a tacit understanding was that farm animals have a bad life. However, they also implied that they felt that they had no choice but to accept alternatives that minimize animal suffering (P21-Well, if the animal is going to have to be condemned by the exploitation tactic of the ... [referring to intensive systems]-because that's the "vibe" [Brazilian slang for trend], right? I mean, they [producers] are so into it, they will not go back from that. So, if there is animal wellbeing, I agree. Because, poor thing, if he is condemned to that, at least we gave him some wellbeing).

Many interviewees suggested that making other types of changes in the different components of the production system would be more appropriate, simple or fair than gene editing to achieve the same goal. For instance, participants suggested that provision of shade or the use of breeds more suited to the climate of the production environment, or the use of pain mitigation or adapting housing to the animals with horns would be more palatable than gene editing for these traits (P1-I think that, to make cattle adapt more to heat, it would be more interesting to invest more in shade than to invest in this genetic thing; P19-If you can have the shade, the shade would be better; P3-A good thing would be to breed it with a zebu [a subspecies of cattle that produce less milk but is more resistant to heat], or something like that.; P16-“... create some engineering to protect [meaning the handler]. Or you can use anti-inflammatory drugs after removing the horn"). Interestingly, even participants that had favourable views about gene editing commented on aspects of the production system that could be improved (P1—there would also have to be investment in changing the rearing systems, not only in genetic improvement, I think it would have to be on both sides).

Some interviewees discussed the education and awareness of producers, assuming that providing information to producers and reflecting on the practices used would drive the adoption of new practices in the production systems and make gene editing unnecessary (P6-The example of sweat glands in the animal, I think it is the one that would most convince me, because the animal suffers in the heat. But even so I think that farmers can rethink their on-farm practices and, instead of deforesting, they should understand that shade is part and will not affect the pasture and will not affect the things that happen there; P1-The question of removing the horns, it is interesting, but it also comes to the question of education, you know, why not use anaesthesia?).

Interviewees that opposed gene editing to produce higher carcass yields proposed measures aimed at changing society, rethinking the production systems including their scale. These interviewees discussed diet diversification, reduction in beef consumption, and changes in production concepts such as production systems that favoured a longer life for the animal (P15-So, what to say, it [gene edition for double musculature phenotype] justifies producing more, but... for example, chickens, 30 days you have a chicken ready to eat and can we say that this is healthy meat for us? Give me a break!. . How can we justify that? I think we have to look for other forms of feeding, perhaps; P17_... greed in production, in economics, always wanting to have meat at all times, in a short time. [...] . . but I think there are alternative forms, you know. Other types of meats and foods... consuming less). Finally, some interviewees questioned whether the use of gene editing in livestock production would be in line with what, in their view, would be the correct path for humanity when considering human health, the environment and feeding the world. Many stated that the reduction in meat consumption was a more sustainable solution for these problems than gene editing (P27-From the point of view of consumption, society will have the benefit of having more meat available, and today we know that society is increasingly carnivorous, that there is a very high demand for food of animal origin. But I think that, in fact, these improvements will not benefit society. In fact, society has to be made aware of the need to reduce consumption and so we don't need these improvements. The more we produce, the more we will be stimulating consumption-which is not an interesting consumption, neither from an environmentally sustainable point of view, nor from a nutritional point of view). One participant questioned whether increased production is necessary (P11-I think we have to ask ourselves "Does production need to be increased? This 
logic of producing more and more, for what? To feed whom? Are there hungry people? Yes, but it is not because there is no food).

\subsubsection{Naturalness of Gene Editing and Violations of the Animals' Integrity}

For most interviewees gene editing was not natural, but many were also nuanced in this discussion acknowledging that naturalness is a complex discussion (P26-... natural and artificial is a kind of complicated discussion; P1-It's a very complicated question, very complicated indeed). Importantly, loss of naturalness was not necessarily perceived as negative $(P 1-\ldots$ it does not mean that it is negative, but for me it is no longer natural). Reasons to consider gene editing as not natural included the fact that humans had interfered with nature (P17_ . . . it is not natural, you are making changes to it [referring to the cow], humans are interfering, it is not an evolution of nature, of the animal. . ; P20_. . it is no longer natural. Natural is what I was born with and will die with. Everything that is infiltrated or removed is not natural), changing the organism (P3-Is that natural to the animal? Historically, or how did he get to that state...growing non-stop?), and the acceleration of natural processes (P31-... I don't think it's the same as natural [...] the end result is the same, but this one took 20 generations that arrived at it.; P18_... in nature, over time, these things happen, so in a way it is natural. But the thing is that you accelerate it, that's when I think no, you can't consider it natural.). Interestingly, some interviewees believed that gene editing could be considered natural and used similar arguments cited by others that considered in not natural when justifying the unnaturalness of the process, i.e., that gene editing is a natural process that has "only" been accelerated (P19_Yes, being the same species [referring to the addition to the genome]. .. It's a natural thing, you are only accelerating what would occur naturally in the environment, it's accelerating it and will benefit even the animal itself; P25-I believe it would happen, right? Nowadays, you have that option to speed up the process. It's natural. P28 -For me, yes. Because they could have this crossing, it would only take more generations to reach the same result. So yes).

However, even when asked to consider that the process could occur naturally and would not differ from what could be found in nature because genes of the same species would be used, many did not consider gene editing natural (P29-I think not. Because even though it's the same species, it can have a side effect, right?; P3-Unless you are going to cross, for example, a cattle from one to another in the natural way, so I think this is natural; now, laboratory genetic editing is artificial), and some doubted whether the change would actually occur in nature $(P 7-\ldots$ although we know it can happen naturally $[. .$.$] it is directed, man did it, then$ it can no longer be said that it is natural. Especially because we cannot predict that this would naturally occur [... I It happens through mechanisms that exist in nature, but that does not mean that it is natural).

Arguments conveying loss of naturalness were often associated with concerns about the violation of the animals' integrity; often in relation to the elimination of a natural characteristic of the animal. This was particularly evident in the POLLED gene editing example, when participants questioned the loss of a part of the animal's body and how this may impact the animal in the long term (P15_... it no longer has the horn, surely something changes in the animal because it no longer has a horn; P9-I don't know how important it is to a cow, how it feels, if it will feel amputated without a horn ... ). There were also questions related to permanent and irreversible changes to the species ( $\mathrm{P} 6$ - So is this not going to get lost? Cattle will become polled, does that mean it won't be that way anymore?) and the creation of "unnatural" beings (P15-This here [referring to the double musculature phenotype] actually stopped being an animal and became an aberration ... ).

\subsubsection{Who Is Trustworthy When Seeking Information on Gene Editing?}

Trust was related to the perception of conflicts of interest regarding who communicates the information, i.e., information coming from industry or a researcher financed by industry was frequently questioned (P29-Who finances the research? It is the producing companies, right?; P23-Look... researchers from universities that are not having their research funded by 
producers, then I trust [them]. And organizations, it depends, nowadays it has to be seen if they are not just a façade, right. But I would trust some organization that I know the background. So, there is a greater predisposition to believe in universities and environmental organizations.). There appeared to be more confidence in scientists from academics (without ties to industry) than those working in government or industry (P24-I think I trust academia more; P27-I mainly trust academia. Although we have many areas today with conflicts of interest. I seek information from both sides to try to form an opinion, but mainly academic sources. I do not trust, mainly, the "agro is pop" [pro-agriculture publicity] of television, that I cannot trust; P31-I trust academia more. ... Yeah, because I think the government, it looks like they will not have enough knowledge, and industry will have the knowledge pruned for their purpose.). Finally, for some there was a generalized lack of trust regardless of who conveyed the information (P28-Nowadays everything is so complicated, you have to research everything yourself and take what you found and compare).

\subsection{Study 2. Descriptive Results}

Participants' distribution of sex, age, and place of residency approximately corresponded to the Brazilian population according to the Brazilian Institute of Geography and Statistics Census (IBGE, 2011) (Table 2). A larger proportion of participants had undergraduate level education (64\%) and slightly higher incomes than the Brazilian population, yet $25 \%$ preferred not to provide this information. Although $7 \%$ of the participants stated that they had grown up with some contact with farm animal production, they specifically stated that they were currently not involved with agriculture. Across all participants only $5 \%$ stated that they had some professional involvement with agriculture.

Table 2. Study 2: Demographics of survey participants $(n=864)$ and of the Brazilian population according to the latest census (IBGE, 2011).

\begin{tabular}{|c|c|c|}
\hline Variable & Participants & IBGE 2011 \\
\hline & $(\%)$ & $(\%)$ \\
\hline \multicolumn{3}{|l|}{ Sex } \\
\hline Female & 52 & 51 \\
\hline Male & 48 & 49 \\
\hline \multicolumn{3}{|l|}{ Age } \\
\hline 18 to 24 years old & 16 & 16 \\
\hline 25 to 34 years old & 18 & 23 \\
\hline 35 to 44 years old & 29 & 20 \\
\hline 45 to 54 years old & 22 & 18 \\
\hline 55 years old and over & 16 & 23 \\
\hline \multicolumn{3}{|l|}{ Current residence } \\
\hline Urban & 89 & 85 \\
\hline Rural & 11 & 15 \\
\hline \multicolumn{3}{|l|}{ Region of Brazil } \\
\hline South & 25 & 15 \\
\hline Southwest & 48 & 42 \\
\hline North & 4 & 8 \\
\hline Northwest & 15 & 28 \\
\hline Centre-West & 9 & 7 \\
\hline \multicolumn{3}{|l|}{ Education } \\
\hline Up to high school & 36 & 64 \\
\hline Undergraduate (complete or ongoing) & 64 & 36 \\
\hline \multicolumn{3}{|l|}{ Household income * } \\
\hline Up to 2 minimum wage & 19 & 24 \\
\hline 2 to 5 minimum wage & 43 & 49 \\
\hline 6 to 10 minimum wage & 23 & 14 \\
\hline Over 10 minimum wage & 15 & 13 \\
\hline
\end{tabular}

* Data referring to income were taken from the Family Budget Survey 2017-2018-IBGE [42]. 
Study 2. Quantitative Results

Acceptability of the three different gene editing applications differed (Figure 1): MG vs. $\mathrm{HR}, \mathrm{V}=69396, p<0.001$; MG vs. POLLED, $\mathrm{V}=8799.5, p<0.001$; HR vs. POLLED, $\mathrm{V}=25004, p<0.001$. Additionally, acceptability was low for all applications, varying from $12 \%$ for MG to $33 \%$ for POLLED. Few participants said that they had read much or very much about genetic modification of animals (33\%) or about gene editing of plants, animals or humans $(33 \%)$. The majority of participants conveyed that they believed there to be more risks ( $11 \%$ none or very low; $21 \%$ intermediate; $68 \%$ high or very high) than benefits ( $42 \%$ none or very low; $31 \%$ intermediate; $27 \%$ high or very high) from the applications of gene editing presented in the survey.

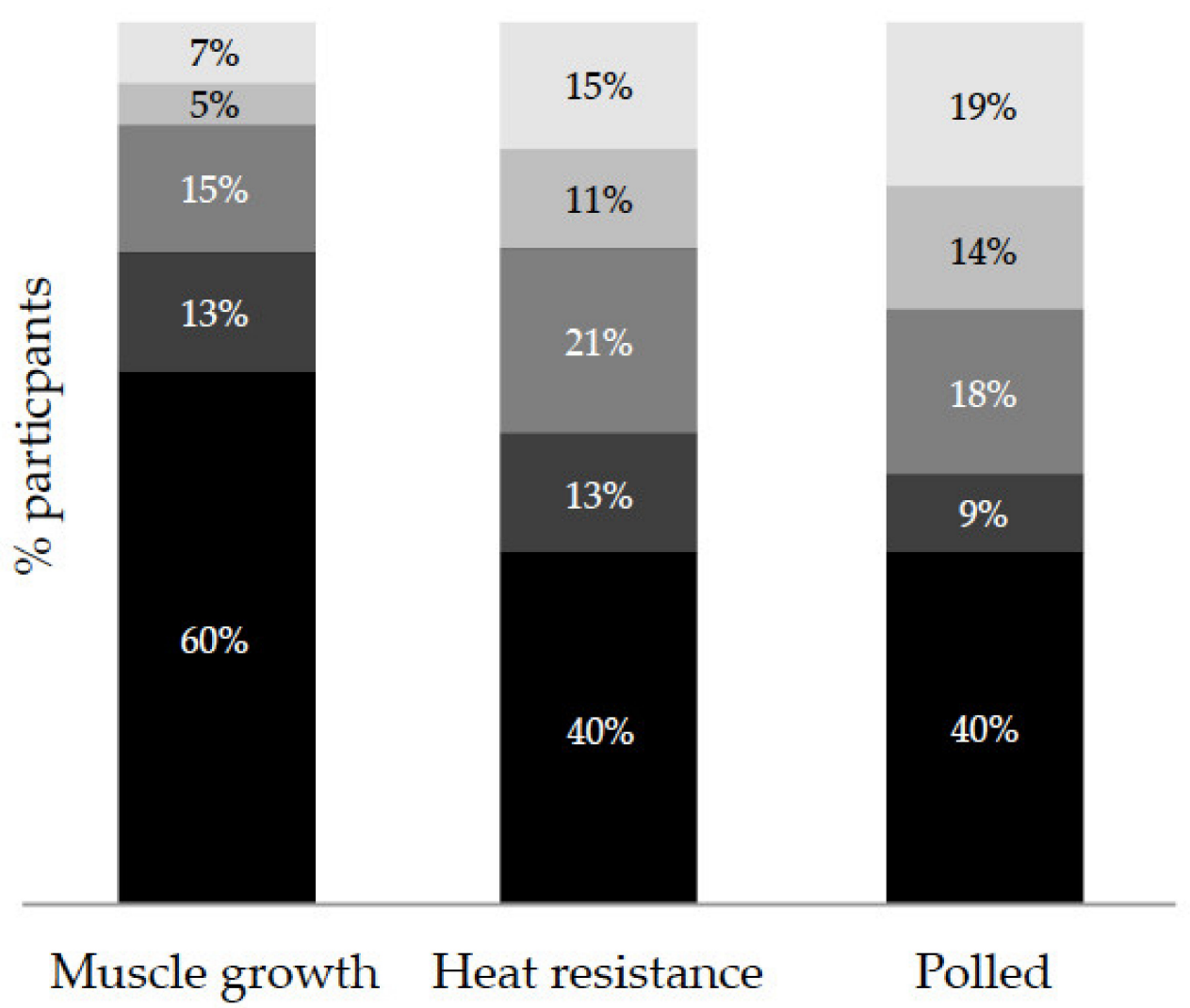

\section{Likert scale $\square 1 \square 2 \square 3 \square 4 \square 5$}

Figure 1. Study 2: Acceptability (Likert scales, ranging from $1=$ not at all acceptable to $5=$ totally acceptable) of using gene editing to modify cattle to be muscle growth, improve heat resistance or polled (\% participants, $n=864$ ).

Demographic variables that influenced acceptability of the MG, HR and POLLED, application are shown in Table 3. Acceptability of the three applications was influenced by sex, age, education, household income, meat consumption and involvement in agriculture, region of residence of the participant. The order of presentation of the applications in the survey did not influence acceptability. 
Table 3. Study 2: Influence of demographic variables of 864 participants on acceptability measured using responses captured using a Likert scale, ranging from $1=$ not at all acceptable to $5=$ totally acceptable to questions about the use of gene editing to modify cattle to either have increased muscle growth or improved heat resistance or be hornless. Means with different letters within each demographic variable are significantly different within columns $(p<0.001)$.

\begin{tabular}{|c|c|c|c|c|}
\hline Variable & & Muscle Growth & Heat Resistance & Polled \\
\hline & $n$ & Mean & Mean & Mean \\
\hline \multicolumn{5}{|l|}{ Sex } \\
\hline Male & 418 & $2.17 \mathrm{a}$ & $2.69 \mathrm{a}$ & $2.90 \mathrm{a}$ \\
\hline Female & 446 & $1.54 \mathrm{~b}$ & $2.26 \mathrm{~b}$ & $2.37 \mathrm{~b}$ \\
\hline \multicolumn{5}{|l|}{ Age } \\
\hline 18 to 24 years old & 134 & $2.14 \mathrm{a}$ & $2.98 \mathrm{a}$ & $2.91 \mathrm{a}$ \\
\hline 25 to 34 years old & 164 & $1.96 \mathrm{ab}$ & $2.60 \mathrm{~b}$ & $2.95 \mathrm{ab}$ \\
\hline 35 to 44 years old & 243 & $1.85 \mathrm{bc}$ & $2.42 \mathrm{~b}$ & $2.60 \mathrm{bc}$ \\
\hline 45 to 54 years old & 186 & $1.74 \mathrm{bc}$ & $2.35 \mathrm{bc}$ & $2.40 \mathrm{c}$ \\
\hline 55 years old and over & 137 & $1.56 \mathrm{c}$ & $2.07 \mathrm{c}$ & $2.31 \mathrm{c}$ \\
\hline \multicolumn{5}{|l|}{ Education } \\
\hline Up to high school & 312 & $1.71 \mathrm{a}$ & 2.49 & $2.54 \mathrm{a}$ \\
\hline Undergraduate (complete or ongoing) & 552 & $1.92 \mathrm{~b}$ & 2.46 & $2.68 \mathrm{~b}$ \\
\hline \multicolumn{5}{|l|}{ Household income } \\
\hline Over 10 minimum wages & 96 & $2.09 \mathrm{ab}$ & $2.59 \mathrm{ab}$ & $2.81 \mathrm{ab}$ \\
\hline 6 to 10 minimum wages & 155 & $2.17 \mathrm{a}$ & $2.79 \mathrm{a}$ & $3.10 \mathrm{a}$ \\
\hline 2 to 5 minimum wages & 280 & $1.87 \mathrm{~b}$ & $2.51 \mathrm{ab}$ & $2.69 \mathrm{~b}$ \\
\hline Up to 2 minimum wages & 121 & $1.48 \mathrm{c}$ & $2.15 \mathrm{c}$ & $2.13 \mathrm{c}$ \\
\hline I prefer not to say & 212 & $1.67 \mathrm{c}$ & $2.32 \mathrm{bc}$ & $2.40 \mathrm{c}$ \\
\hline \multicolumn{5}{|l|}{ Food consumption } \\
\hline All animal products & 791 & $1.90 \mathrm{a}$ & $2.53 \mathrm{a}$ & $2.69 \mathrm{a}$ \\
\hline Vegetarian or vegan & 73 & $1.25 \mathrm{~b}$ & $1.83 \mathrm{~b}$ & $2.01 \mathrm{~b}$ \\
\hline \multicolumn{5}{|l|}{ Involvement in agriculture } \\
\hline No & 763 & $1.81 \mathrm{a}$ & $2.41 \mathrm{a}$ & $2.57 \mathrm{a}$ \\
\hline Grew up in environment & 56 & $1.98 \mathrm{ab}$ & $2.57 \mathrm{a}$ & $2.57 \mathrm{a}$ \\
\hline Yes & 45 & $2.33 \mathrm{~b}$ & $3.31 \mathrm{~b}$ & $3.71 \mathrm{~b}$ \\
\hline
\end{tabular}

\section{Discussion}

Interview participants considered gene editing of cattle more acceptable if the application was viewed to reduce animal suffering, but less acceptable if it was perceived to harm the animals; similar findings were also reported in studies conducted in other countries $[26,29,43,44]$. A perception of loss of naturalness associated with gene editing was almost consensual; however, this was not directly associated with acceptability of the technology, but reflected direct criticisms of the production systems, including confined housing, lack of shade (to mitigate heat stress), and unnaturally fast growth cycles. A key element shaping acceptability of using gene editing in cattle was concerns about the distribution of potential risks and benefits among each of the beneficiaries, including consumers, the animals, farmers, and corporations. Participants considered gene editing capital intensive, which raised concerns that it could benefit large scale farmers and corporations, but be riskier for small scale farmers. Overall, concerns about using gene editing in cattle raised by participants were less related to intrinsic characteristics of the technology, but rather seemed to mirror general concerns about the impacts of livestock production practices on animals, humans and the environment. For many, gene editing was seen as the final straw in solidifying their negative views of animal agriculture. The extent to which members of the public adopt this type of abolitionist view of animal agriculture will no doubt have a profound impact on the future sustainability of animal agriculture.

The quantitative study, corroborating the qualitative findings, indicated that acceptability of gene editing depends on the type and purpose of application proposed. The participants considered the use of gene editing to improve muscle tissue growth less acceptable than that used to reduce heat stress or to produce polled cattle. Demographic variables influenced acceptability of the three applications. Men, younger participants, 
meat consumers, participants associated with livestock production and those with a higher income found all three gene editing applications more acceptable. Although participants that declared involvement with livestock production found gene editing more acceptable than participants with no involvement, acceptance in this group was low. Given the low number of participants in this category and lack of details regarding the nature of involvement in the sector, we suggest that further studies should investigate the attitudes towards gene editing of this demographic category. As shown in other studies investigating acceptability of genetically modified food in North America, Europe and the UK, acceptability of gene editing applications was lower among women and younger participants $[28,44,45]$. Although knowledge of genetics was not measured in this study, we did find that people with higher levels of education tended to be more positive to gene editing. Some studies showed a positive correlation between basic knowledge of genetic concepts and acceptability of genetic modifications and knowledge [44,46]. The quantitative survey used a convenience sample; therefore, even if the overall demographics closely match the Brazilian census data [41] except for education, these findings cannot be generalized to the Brazilian population. It is noteworthy that the sample comes from a relevant pool of Brazilian citizens, as an estimated 99 million, or $47 \%$ of the population use Instagram (58\% women, $55 \%$ of whom are between 18 and 34 years-old, and 36\% between 35 and 64 years-old) [47]. However, it is also noteworthy that interview participants had a similar sex and age distribution and were also urbanites, but were more educated, which may be considered when interpreting the findings of the qualitative study.

Our findings are in line with the idea that what drives people to a critical moral judgment of gene editing is not the associations with genetically modified organisms or the technology itself, but rather its application or intended uses [48]. Gene editing applications were deemed more acceptable if seen as more beneficial than dangerous or harmful. The most important perceived benefit was the reduction in animal suffering, which seemed to offset some concerns about modifying the animals' telos and unforeseen downstream effects. Additionally, participants tended to reject gene editing applications when they perceived them as unable to provide benefits to the animals, beyond and regardless of any utility to humans. According to Lassen et al. [49], people tend to question the utility of animal biotechnology applications and do not endorse them when they see them as being merely about economic gains. Likewise, more recent work [26] showed that citizens are more likely to accept gene editing of farm animals when the applications provide demonstrable public good, such as animal welfare and worker safety. Citizens' ethical concerns regarding genetic modification technologies encompass the social and economic implications of these technologies, including how they may be distributed and which impacts they may have on producers $[23,50]$. Although the producers were seen by many as the party to reap the most benefits (more than consumers or the animals), some participants questioned whether all producers would have access to the technology and how would benefit from it. We see this as a relevant point of discussion, as gene editing is a high-cost technology that may be less accessible to many smaller producers. One such example is the use of sexed semen, which was presented as a tool to obtain an adequate supply of dairy replacement heifers in the dairy industry, and it was expected that its widespread application would reduce the cost of milk production and milk prices [51] and improve animal welfare [52,53]. However, sexed semen is more expensive and less efficient than promised [54], which limits its use by farmers [55]. In many cases support for gene editing from some participants sounded more like resignation than trust in the potential of the technology. For example, some participants welcomed gene editing in view of farmers' lack of willingness to use adapted breeds or pain medications for dehorning. This view was discussed by Shriver and McConnachie [56] as "gene editing as preferable to the status quo", based on the principle that if gene editing can improve animal welfare compared to current systems, its adoption would be the most ethical choice. Overall, the main concerns regarding the use of gene editing in farm animals were not about the genetic modification 
of animals per se, but rather about the types of modification that could be performed, for what purpose, who benefits and who pays.

As in other surveys [29,44], lower support for gene editing was identified among participants that were concerned with downstream biological and societal risks. This included unknown outcomes, which in some cases was anchored in low understanding of familiarity with the technology. These attitudes advocate the importance of familiarizing people with the "entire picture", including the pros and cons of a new technology. Some authors warn that the potential risks to animals, humans, the environment and society need to be better understood [57-60]. Yet, it is important to bear in mind that lay people tend to assess the risks of technologies, especially the acceptability of such risks, differently from specialists [61], so risk analyses must embrace scientific and social perspectives. As our findings suggest, when people become aware of the practices and reasons behind their use in the animal industry, new questions emerge about why animals are treated as they are in these systems or why some interventions are necessary, or whether the adoption of gene editing will produce significant changes to the system. It is well established that the lay public has little knowledge about production practices [7,10,62]; thus, trying to justify gene editing on the basis of some practices that are apparently very positive, such as the end of routine painful procedures like dehorning and castration or diseases in animals [19], comes with the risk of revealing to the public the conditions under which farm animals are being raised and may increase concerns. Simply informing the public, even if it is with technical justifications, about the limitations of animal husbandry is not enough to improve attitudes [63].

Few participants considered gene editing as natural. For some, the fact that gene editing is obtained with human interference is sufficient to justify a loss of naturalness, even if the results obtained with the gene editing were similar to phenotypes found in nature. Some have argued that the physical identity of the object (i.e., horned or polled) is not so important in the public's perception of naturalness, but rather if in the history of the object there were changes caused by humans [64]; for some people, being untouched by humans is the basis of naturalness [65]. The belief that historical evolution creates perfectly adapted plants and animals [66] may explain why the acceleration of the natural process is a key point supporting the perception of loss of naturalness. Naturalness (or the lack thereof) has been considered to be an important aspect when regulating gene editing. For example, in the European Union, gene edited products are considered unnatural and therefore subject to regulations for transgenics [67]; in contrast, in the USA, it is proposed that they be considered like any other natural product [68]. A survey with US and French consumers, reported that they felt that gene editing-based foods should be treated as GMO-based foods [69]. Some authors believe that, given the absence of foreign DNA, gene editing has the potential to be perceived by consumers as less unnatural than previous transgenic technologies, which would have implications for acceptability [43,70]. Our study does not support this approach; the absence of foreign DNA (from another species) did not seem to influence participants' opinions regarding the naturalness of gene editing. Legislation created for Brazil should take into account the perception of the Brazilian public.

Naturalness does not appear to have a direct relationship with acceptability of gene editing, as shown in a study with American citizens [44]. Yet, perceptions of naturalness do appear to indirectly influence attitudes towards gene editing, as many people see natural systems as healthier and capable of providing better welfare for animals [71-73]. In a meta-analysis carried out in Europe and North America, Román et al. [74] concluded that the naturalness of food is crucial for most consumers and the failure to consider this may undermine sustainability. Our findings suggest that the introduction of gene editing in livestock production in Brazil (and perhaps other countries) is initially not likely to face significant public resistance. However, it may contribute to the growing concerns regarding technologies used in farm animal production, including antibiotics, synthetic hormones and pesticides, which are perceived to pose risks to human, animal, and environmental health and are often associated with intensive large farm systems [6,7]. This, added to 
the suspicion expressed by many participants that gene editing may be a substitute for good husbandry, suggests that introducing gene editing into livestock production may come at the expense of public trust in the industry, potentially causing the public to seek alternative non-gene edited products or elect to simply shy away from all animal food products. Although attitudes towards animal welfare do not always translate into purchasing behaviour $[75,76]$, these attitudes may cause moral discomfort and may be expressed in other ways, such as support for changes in legislation [77]. Additionally, many consumers see alternative, non-animal products as a path to more sustainable food options and a way to deal with the problem of farm animal welfare $[37,78,79]$. For example, analysts suggest that widespread consumer acceptance of lab-cultured products will depend mainly on the price and organoleptic characteristics of the products [80,81] and perceived loss of naturalness, which is a universal concern and thus an important factor in the acceptance of cultured meats [82-84]. The results of a recent survey showed that the message that conventional meat is unnatural was the most effective way to gain support for cultured meat; in contrast, arguing for the unimportance of naturalness had no effect [85]. Thus, caution is warranted when introducing new gene editing technologies as they may in fact further exacerbate already existing concerns of loss of naturalness. This may be particularly relevant in the case of animal food industries that are already facing competition from plant-based alternatives and, sometime in the future, from "cellular agriculture" [86].

Participants also addressed the morality of using gene editing to modify animals for human benefit. For some participants, using gene editing to modify the animals to produce more or to adapt them to the housing or rearing systems is simply wrong. Similarly, others have argued that the process of gene editing allows the human to take "control" of animal life, and this added control adds to the already present asymmetry of the human-animal relationship [87], which favours humans [88].

The changing of the animal's telos using gene editing was a recurrent concern raised in the interviews, and included comments that were beyond what has previously been discussed in the scientific literature [89-91]. The most common view raised by many of our participants agrees with the argument of Rollin [89], for whom genetic engineering is a morally neutral tool that is acceptable if the modification increases animal welfare, yet becomes ethically unacceptable when the modification of the animal's telos makes the animal undergo negative experiences. However, for other participants, using gene editing to increase heat tolerance and to introduce hornlessness was not so straightforward. Although they were reticent given that the technology modified the telos of cattle, they viewed the former to be more acceptable because it favours the animal but found the latter less acceptable because the resulting change entails a loss (in the case of the horn) for the animal or the species. This nuanced line of thinking is in agreement with Kramer and Meijboom's [91] view of telos; whereby, modifications that favour robustness are acceptable, but not when they alter the animal physically to replace invasive physical interventions. Lastly, and in accordance to Ishii [90], some interviewees considered that changes in the traits of animals that can be visualized (e.g., the loss of horns or the addition of prominent musculature), as a violation of the animals' telos.

Farm animals go through several painful "routine management" interventions such as debeaking, dock tailing and disbudding and many farm animal species have been genetically selected for high production and develop at faster growth rates [92]. Many scientists have also presented gene editing as a tool to improve animal production, health and welfare, and to face environmental and climate challenges [12,13,93-95]. According to some, gene editing could "pave the way to a more sustainable future for livestock agriculture" [70]. Our findings suggest that at least part of the public may have different views regarding how to address the main concerns posed by the intensification of livestock production on the animals, consumers and farmers; for some, gene editing may not solve but reinforce these problems. A common feeling amongst our participants was that additionally to, or instead of, changing animals to make them fit their environment, husbandry practices and systems should be changed to improve the wellbeing of animals. Animal welfare was 
the most salient topic discussed by participants, but they also addressed sustainability of production systems through a wider lens including aspects of the environment, animals and humans. The premise that the use of gene editing technologies can promote sustainably per se is in line with the "sustainable intensification" approach, which may not fully address farm animal welfare [96] as well as other social and environmental societal aspirations [22]. It is true that some scientists are interested in unveiling potential concerns that may need to be addressed before gene editing can be applied in animals. However, a recent systematic review [97] identified some issues that are underrepresented in the academic literature, including equity of access to the potential benefits of gene editing technologies, animal-related concerns and impacts of the moral status of animals-three issues that appeared as the main concerns raised by the lay citizens in this study and also by others studying North American and Brazilian citizens [26,29,43,44]. The participants in our survey stated that they rely more on the academy of science to provide them information on gene editing because, in their perception, academics possess the greatest knowledge on the subject and represent the interests of society. In contrast, governments, companies and NGOs were seen as less reliable, as they may manipulate information according to their interests. Others have shown that trust in science and in scientists is relatively high in Brazil $[36,98]$, where universities are seen as the most trusted source for information on genetically modified organisms [99] and animal-related issues [6]. In a study involving the debate around transgenic crops in Brazil, citizens discredited scientists with links to industry and the media, arguing that they have no commitment with public interest [100]. In order to retain public trust, scientists should strive to address some of the concerns expressed by citizens in this and other surveys, to help elucidate the potential risks of gene editing in farm animals for consumers, the animals, the environment and the farming community.

\section{Conclusions}

In line with many in the scientific community that present it as a promising tool to contribute to the sustainability of animal agriculture, some participants did acknowledge the potential for gene editing to help tackle animal production, health and welfare challenges. The acceptability of gene editing in cattle was increased by perceptions of benefits for animal welfare. However, it was reduced when the perceptions of risks and benefits were viewed as unevenly or unfairly distributed among consumers, corporations, different types of farmers, and the animals. Our findings also suggest that incorporating gene editing within the farm animal systems may contribute to the growing public perception of the loss of naturalness, which may potentially erode consumers' preference for animal products. Our findings raised several issues that may need to be addressed for gene editing to comply with the social aspect of sustainable agriculture.

Supplementary Materials: The following are available online at https:/ /www.mdpi.com/article/10 .3390/su13094966/s1: Table S1: Script of the questionnaire study 2. Study 2 data are available from the corresponding author on request.

Author Contributions: Conceptualization, M.J.H. and M.C.Y.; methodology, M.J.H. and M.C.Y.; formal analysis, M.J.H., M.C.Y. and Z.O.-S.; investigation, M.J.H., M.C.Y. and Z.O.-S.; writingoriginal draft preparation, M.C.Y. and Z.O.-S.; writing—review and editing, M.J.H., M.C.Y. and M.A.G.v.K.; supervision, M.J.H. and M.A.G.v.K.; funding acquisition, M.J.H. All authors have read and agreed to the published version of the manuscript.

Funding: CNPq (National Council for Scientific and Technological Development, Brazil) grant number 404403/2016-6. MJH was supported by CNPq (P. 311509/2015-0). This research received no external funding.

Institutional Review Board Statement: Study 1 was approved by Ethics Committee on Experimentation of the Santa Catarina State University (P. 2.051.639). All procedures in Study 2 followed the ethical principles established by Regulations n. 466/2012 and 510/2016 from CNS, the Brazilian 
National Health Council, that stipulate that online surveys that do not identify participants are exempted from evaluation by Ethic Committees.

Informed Consent Statement: Informed consent was obtained from all subjects involved in the study.

Data Availability Statement: The following are openly available online at https:/ figshare.com/ articles/dataset/sustainability-1187163_data/14510076: Supplement 1 (Table S1: Script of the questionnaire study); Supplement 2 (Presentation used in study 2); data presented in study 2.

Acknowledgments: We are grateful to citizens that voluntarily participated in the two studies and two anonymous reviewers for your valuable comments and suggestion.

Conflicts of Interest: The authors declare no conflict of interest.

\section{References}

1. Milne, M.J.; Gray, R. W (h) ither Ecology? The Triple Bottom Line, the Global Reporting Initiative, and Corporate Sustainability Reporting. J. Bus. Ethics 2013, 118, 13-29. [CrossRef]

2. Von Keyserlingk, M.A.G.; Martin, N.P.; Kebreab, E.; Knowlton, K.F.; Grant, R.J.; Stephenson, M., II; Sniffen, C.J.; Harner, J.R., III; Wright, A.D.; Smith, S.I. Invited review: Sustainability of the US dairy industry. J. Dairy Sci. 2013, 96, 5405-5425. [CrossRef]

3. Von Keyserlingk, M.A.G.; Hötzel, M.J. The ticking clock: Addressing farm animal welfare in emerging countries. J. Agric. Environ. Ethics 2015, 28, 179-195. [CrossRef]

4. Rollin, B.E. Animal Rights as a Mainstream Phenomenon. Animals 2011, 1. [CrossRef] [PubMed]

5. Miele, M.; Veissier, I.; Evans, A.; Botreau, R. Animal welfare: Establishing a dialogue between science and society. Anim. Welf. 2011, 20, 103-117.

6. Hötzel, M.J.; Yunes, M.C.; Vandresen, B.; Albernaz-Gonçalves, R.; Woodroffe, R.E. On the Road to End Pig Pain: Knowledge and Attitudes of Brazilian Citizens Regarding Castration. Animals 2020, 10, 1826. [CrossRef] [PubMed]

7. Cardoso, C.; von Keyserlingk, M.; Hötzel, M.J. Brazilian citizens: Expectations regarding dairy cattle welfare and awareness of contentious practices. Animals 2017, 7, 89. [CrossRef]

8. Verbeke, W. Stakeholder, citizen and consumer interests in farm animal welfare. Anim. Welf. 2009, 18, 325-333.

9. Maria, G.A. Public perception of farm animal welfare in Spain. Livest. Sci. 2006, 103, 250-256. [CrossRef]

10. De Barcellos, M.D.; Krystallis, A.; de Melo Saab, M.S.; Kuegler, J.O.; Grunert, K.G. Investigating the gap between citizens' sustainability attitudes and food purchasing behaviour: Empirical evidence from Brazilian pork consumers. Int. J. Consum. Stud. 2011, 35, 391-402. [CrossRef]

11. Teixeira, D.L.; Larraín, R.; Hötzel, M.J. Are views towards egg farming associated with Brazilian and Chilean egg consumers' purchasing habits? PLoS ONE 2018, 13, e0203867. [CrossRef]

12. Proudfoot, C.; Mcfarlane, G.; Whitelaw, C.B.A.; Lillico, S.G. Livestock breeding for the 21st century: The promise of the editing revolution. Front. Agric. Sci. Eng. 2020. [CrossRef]

13. Lamas-Toranzo, I.; Guerrero-Sánchez, J.; Miralles-Bover, H.; Alegre-Cid, G.; Pericuesta, E.; Bermejo-Álvarez, P. CRISPR is knocking on barn door. Reprod. Domest. Anim. 2017, 52, 39-47. [CrossRef] [PubMed]

14. Maga, E.; Murray, J. Welfare applications of genetically engineered animals for use in agriculture. J. Anim. Sci. 2010, 88, 1588-1591. [CrossRef] [PubMed]

15. Tan, W.; Carlson, D.F.; Lancto, C.A.; Garbe, J.R.; Webster, D.A.; Hackett, P.B.; Fahrenkrug, S.C. Efficient nonmeiotic allele introgression in livestock using custom endonucleases. Proc. Natl Acad. Sci. USA 2013, 110, 16526-16531. [CrossRef]

16. Dikmen, S.; Khan, F.A.; Huson, H.J.; Sonstegard, T.S.; Moss, J.I.; Dahl, G.E.; Hansen, P.J. The SLICK hair locus derived from Senepol cattle confers thermotolerance to intensively managed lactating Holstein cows. J. Dairy Sci. 2014, 97, 5508-5520. [CrossRef] [PubMed]

17. Sonstegard, T.S.; Carlson, D.F.; Fahrenkrug, S.C. Genetically Modified Animals Having Increased Heat Tolerance. WO2017053315A1, 30 March 2017.

18. Proudfoot, C.; Carlson, D.F.; Huddart, R.; Long, C.R.; Pryor, J.H.; King, T.J.; Lillico, S.G.; Mileham, A.J.; McLaren, D.G.; Whitelaw, C.; et al. Genome edited sheep and cattle. Transgenic Res. 2015, 24, 147-153. [CrossRef]

19. Menchaca, A.; dos Santos-Neto, P.C.; Mulet, A.P.; Crispo, M. CRISPR in livestock: From editing to printing. Theriogenology 2020. [CrossRef] [PubMed]

20. Wei, C.; Liu, J.; Yu, Z.; Zhang, B.; Gao, G.; Jiao, R. TALEN or Cas9-rapid, efficient and specific choices for genome modifications. J Genet Genom. 2013, 40, 281-289. [CrossRef]

21. Baltimore, D.; Berg, P.; Botchan, M.; Carroll, D.; Charo, R.A.; Church, G.; Corn, J.E.; Daley, G.Q.; Doudna, J.A.; Fenner, M. A prudent path forward for genomic engineering and germline gene modification. Science 2015, 348, 36-38. [CrossRef]

22. Bruce, A. Gene editing animals-part of a utopian future? In Food Futures: Ethics, Science and Culture; Olsson, A.S., Araújo, S.M., Vieira, M.F., Eds.; Wageningen Academic Publishers: Wageningen, The Netherlands, 2016; pp. 513-517.

23. Lusk, J.L.; McFadden, B.R.; Wilson, N. Do consumers care how a genetically engineered food was created or who created it? Food Policy 2018, 78, 81-90. [CrossRef]

24. Shriver, A. Prioritizing the protection of welfare in gene-edited livestock. Anim. Front. 2020, 10, 39-44. [CrossRef] 
25. Pardo, R.; Midden, C.; Miller, J.D. Attitudes toward biotechnology in the European Union. J. Biotechnol. 2002, 98, 9-24. [CrossRef]

26. Ritter, C.; Shriver, A.; McConnachie, E.; Robbins, J.; von Keyserlingk, M.A.G.; Weary, D.M. Public attitudes toward genetic modification in dairy cattle. PLoS ONE 2019, 14, e225372. [CrossRef]

27. Gaskell, G.; Allum, N.; Bauer, M.; Durant, J.; Allansdottir, A.; Bonfadelli, H.; Boy, D.; de Cheveigné, S.; Fjaestad, B.; Gutteling, J.M.; et al. Biotechnology and the European public. Nat. Biotechnol. 2000, 18, 935. [CrossRef]

28. Costa-Font, M.; Gil, J.M.; Traill, W.B. Consumer acceptance, valuation of and attitudes towards genetically modified food: Review and implications for food policy. Food Policy 2008, 33, 99-111. [CrossRef]

29. Yunes, M.C.; Teixeira, D.L.; von Keyserlingk, M.A.G.; Hötzel, M.J. Is gene editing an acceptable alternative to castration in pigs? PLoS ONE 2019, 14, e0218176. [CrossRef] [PubMed]

30. Frewer, L.J.; Howard, C.; Shepherd, R. Public concerns in the united kingdom about general and specific applications of genetic engineering: Risk, benefit, and ethics. Sci. Technol. Hum. Values 1997, 22, 98-124. [CrossRef]

31. Ribeiro, T.G.; Barone, B.; Behrens, J.H. Genetically modified foods and their social representation. Food Res. Int. 2016, 84, 120-127. [CrossRef]

32. Rollin, B.E. Science and Ethics; Cambridge University Press: Cambridge, UK, 2006.

33. Gaskell, G.; Allansdottir, A.; Allum, N.; Fischler, C.; Hampel, J.; Jackson, J.; Kronberger, N.; Mejlgaard, N.; Revuelta, G.; Schreiner, C.; et al. Europeans and Biotechnology in 2005: Patterns and Trends. A report to the European Commission's Directorate General for Research; London School of Economics and Political Science: London, UK, 2006.

34. Slovic, P. Trust, emotion, sex, politics, and science: Surveying the risk-assessment battlefield. Risk Anal. 1999, 19, 689-701. [CrossRef] [PubMed]

35. Saba, A.; Messina, F. Attitudes towards organic foods and risk/benefit perception associated with pesticides. Food Qual. Pref. 2003, 14, 637-645. [CrossRef]

36. Castelfranchi, Y.; Vilela, E.M.; Lima, L.B.D.; Moreira, I.D.C.; Massarani, L. Brazilian opinions about science and technology: The 'paradox' of the relation between information and attitudes. Hist. Cienc. Saúde-Manguinhos 2013, 20, 1163-1183. [CrossRef] [PubMed]

37. Valente, J.D.P.S.; Fiedler, R.A.; Sucha Heidemann, M.; Molento, C.F.M. First glimpse on attitudes of highly educated consumers towards cell-based meat and related issues in Brazil. PLOS ONE 2019, 14, e0221129. [CrossRef]

38. Drever, E. Using Semi-Structured Interviews in Small-Scale Research: A Teacher's Guide; ERIC: Edinburgh, UK, $1995 ;$ p. 98.

39. Braun, V.; Clarke, V. Using thematic analysis in psychology. Qual. Res. Psychol. 2006, 3, 77-101. [CrossRef]

40. Braun, V.; Clarke, V.; Hayfield, N.; Terry, G. Thematic Analysis. In Handbook of Research Methods in Health Social Sciences; Liamputtong, P., Ed.; Springer: Singapore, 2019; pp. 843-860.

41. IBGE. Sinopse do Censo Demográfico. 2010. Available online: http://biblioteca.ibge.gov.br/visualizacao/livros/liv49230.pdf (accessed on 20 June 2020).

42. IBGE. Pesquisa de Orçamentos Familiares: 2017-2018: Primeiros Resultados. Available online: https://biblioteca.ibge.gov.br/ index.php/biblioteca-catalogo?view=detalhes\&id=2101670 (accessed on 23 April 2020).

43. Kilders, V.; Caputo, V. Is Animal Welfare Promoting Hornless Cattle? Assessing Consumer's Valuation for Milk from Gene-edited Cows under Different Information Regimes. J. Agric. Econ. 2021. [CrossRef]

44. McConnachie, E.; Hötzel, M.J.; Robbins, J.A.; Shriver, A.; Weary, D.M.; von Keyserlingk, M.A.G. Public attitudes towards genetically modified polled cattle. PLoS ONE 2019, 14, e0216542. [CrossRef] [PubMed]

45. Mallinson, L.; Russell, J.; Cameron, D.D.; Ton, J.; Horton, P.; Barker, M.E. Why rational argument fails the genetic modification (GM) debate. Food Secur. 2018, 10, 1145-1161. [CrossRef]

46. Fernbach, P.M.; Light, N.; Scott, S.E.; Inbar, Y.; Rozin, P. Extreme opponents of genetically modified foods know the least but think they know the most. Nat. Hum. Behav. 2019, 3, 251-256. [CrossRef]

47. Statista. Leading Countries Based on Instagram Audience size as of January 2021. Available online: https://www.statista.com/ statistics/578364/countries-with-most-instagram-users/ (accessed on 15 April 2020).

48. Gaskell, G.; Bard, I.; Allansdottir, A.; da Cunha, R.V.; Eduard, P.; Hampel, J.; Hildt, E.; Hofmaier, C.; Kronberger, N.; Laursen, S.; et al. Public views on gene editing and its uses. Nat. Biotechnol. 2017, 35, 1021-1023. [CrossRef]

49. Lassen, J.; Gjerris, M.; Sandøe, P. After Dolly-Ethical limits to the use of biotechnology on farm animals. Theriogenology 2006, 65, 992-1004. [CrossRef] [PubMed]

50. Macnaghten, P.; Guivant, J.S. Converging citizens? Nanotechnology and the political imaginary of public engagement in Brazil and the United Kingdom. Public Underst. Sci. 2011, 20, 207-220. [CrossRef]

51. De Vries, A.; Overton, M.; Fetrow, J.; Leslie, K.; Eicker, S.; Rogers, G. Exploring the Impact of Sexed Semen on the Structure of the Dairy Industry. J. Dairy Sci. 2008, 91, 847-856. [CrossRef]

52. Ritter, C.; Beaver, A.; von Keyserlingk, M.A.G. The complex relationship between welfare and reproduction in cattle. Reprod. Domest. Anim. 2019, 54, 29-37. [CrossRef]

53. Barkema, H.W.; von Keyserlingk, M.A.G.; Kastelic, J.P.; Lam, T.J.G.M.; Luby, C.; Roy, J.P.; LeBlanc, S.J.; Keefe, G.P.; Kelton, D.F. Invited review: Changes in the dairy industry affecting dairy cattle health and welfare. J. Dairy Sci. 2015, 98, 7426-7445. [CrossRef] [PubMed]

54. Weigel, K.A. Exploring the Role of Sexed Semen in Dairy Production Systems. J. Dairy Sci. 2004, 87, E120-E130. [CrossRef] 
55. Balzani, A.; do Amaral, C.A.V.; Hanlon, A. A Perspective on the Use of Sexed Semen to Reduce the Number of Surplus Male Dairy Calves in Ireland: A Pilot Study. Front. Vet. Sci. 2021, 7. [CrossRef]

56. Shriver, A.; McConnachie, E. Genetically Modifying Livestock for Improved Welfare: A Path Forward. J. Agric. Environ. Ethics 2018, 31, 161-180. [CrossRef]

57. Whitall, H. Ethical challenges related to genome editing. In Proceedings of the American Association for the Advancement of Science, Boston MA, USA, 16-20 February 2017.

58. Shriver, A.; McConnachie, E. Genetic Engineering and Animal Welfare. In Encyclopedia of Food and Agricultural Ethics; Thompson, P.B., Kaplan, D.M., Eds.; Springer: Dordrecht, The Netherlands, 2017.

59. Caplan, A.L.; Parent, B.; Shen, M.; Plunkett, C. No time to waste-the ethical challenges created by CRISPR. EMBO Rep. 2015, 16, 1421-1426. [CrossRef]

60. Eriksson, S.; Jonas, E.; Rydhmer, L.; Röcklinsberg, H. Invited review: Breeding and ethical perspectives on genetically modified and genome edited cattle. J. Dairy Sci. 2018, 101, 1-17. [CrossRef] [PubMed]

61. Hansen, J.; Holm, L.; Frewer, L.; Robinson, P.; Sandøe, P. Beyond the knowledge deficit: Recent research into lay and expert attitudes to food risks. Appetite 2003, 41, 111-121. [CrossRef]

62. Stampa, E.; Schipmann-Schwarze, C.; Hamm, U. Consumer perceptions, preferences, and behavior regarding pasture-raised livestock products: A review. Food Qual. Pref. 2020, 82, 103872. [CrossRef]

63. Hötzel, M.J.; Roslindo, A.; Cardoso, C.S.; von Keyserlingk, M.A.G. Citizens' views on the practices of zero-grazing and cow-calf separation in the dairy industry: Does providing information increase acceptability? J. Dairy Sci. 2017, 100, 4150-4160. [CrossRef]

64. Rozin, P. Naturalness judgments by lay Americans: Process dominates content in judgments of food or water acceptability and naturalness. Judgm. Decis. Mak. 2006, 1,91.

65. Scott, S.E.; Rozin, P. Actually, natural is neutral. Nat. Hum. Behav. 2020. [CrossRef]

66. Macnaghten, P. Animals in their nature: A case study on public attitudes to animals, genetic modification and 'Nature'. Sociology 2004, 38, 533-551. [CrossRef]

67. EU. Directive 2001/18/EC of the European Parliament and of the Council of 12 March 2001 on the deliberate release into the environment of genetically modified organisms and repealing Council Directive 90/220/EEC. 2001. Available online: https:/ / eur-lex.europa.eu/LexUriServ/LexUriServ.do?uri=CONSLEG:2001L0018:20080321:EN:PDF (accessed on 18 April 2021).

68. Van Eenennaam, A.L.; Wells, K.D.; Murray, J.D. Proposed U.S. regulation of gene-edited food animals is not fit for purpose. Npj Sci. Food 2019, 3, 3. [CrossRef] [PubMed]

69. Marette, S.; Disdier, A.-C.; Beghin, J.C. A comparison of EU and US consumers' willingness to pay for gene-edited food: Evidence from apples. Appetite 2021, 159, 105064. [CrossRef] [PubMed]

70. McFarlane, G.R.; Salvesen, H.A.; Sternberg, A.; Lillico, S.G. On-Farm Livestock Genome Editing Using Cutting Edge Reproductive Technologies. Front. Sustain. Food Syst. 2019, 3. [CrossRef]

71. Vigors, B.; Ewing, D.A.; Lawrence, A.B. Happy or healthy? How members of the public prioritise farm animal health and natural behaviours. PLoS ONE 2021, 16, e247788. [CrossRef] [PubMed]

72. Yunes, M.C.; von Keyserlingk, M.A.G.; Hötzel, M.J. Brazilian citizens' opinions and attitudes about farm animal production systems. Animals 2017, 7, 75. [CrossRef] [PubMed]

73. Clark, B.; Stewart, G.B.; Panzone, L.A.; Kyriazakis, I.; Frewer, L.J. A systematic review of public attitudes, perceptions and behaviours towards production diseases associated with farm animal welfare. J. Agric. Environ. Ethics 2016, 29, 455-478. [CrossRef]

74. Román, S.; Manuel Sanchez-Siles, L.; Siegrist, M. The importance of food naturalness for consumers: Results of a systematic review. Trends Food Sci. Technol. 2017, 67, 44-57. [CrossRef]

75. Harvey, D.; Hubbard, C. Reconsidering the political economy of farm animal welfare: An anatomy of market failure. Food Policy 2013, 38, 105-114. [CrossRef]

76. Vermeir, I.; Verbeke, W. Sustainable food consumption: Exploring the consumer "attitude-behavioral intention" gap. J. Agric. Environ. Ethics 2006, 19, 169-194. [CrossRef]

77. Tonsor, G.T.; Wolf, C.A. Drivers of resident support for animal care oriented ballot initiatives. J. Agric. Appl. Econ. 2010, 42, 419-428. [CrossRef]

78. Chriki, S.; Hocquette, J.-F. The Myth of Cultured Meat: A Review. Front. Nutr. 2020, 7, 7. [CrossRef] [PubMed]

79. Bogueva, D.; Marinova, D. Cultured Meat and Australia's Generation Z. Front. Nutr. 2020, 7. [CrossRef] [PubMed]

80. Verbeke, W.; Sans, P.; Van Loo, E.J. Challenges and prospects for consumer acceptance of cultured meat. J. Integr. Agric. 2015, 14, 285-294. [CrossRef]

81. Bryant, C.; Barnett, J. Consumer Acceptance of Cultured Meat: An Updated Review (2018-2020). Appl. Sci. 2020, 10, 5201. [CrossRef]

82. Siegrist, M.; Hartmann, C. Perceived naturalness, disgust, trust and food neophobia as predictors of cultured meat acceptance in ten countries. Appetite 2020, 155, 104814. [CrossRef]

83. Laestadius, L.I.; Caldwell, M.A. Is the future of meat palatable? Perceptions of in vitro meat as evidenced by online news comments. Public Health Nutr. 2015, 18, 2457-2467. [CrossRef] [PubMed]

84. Bryant, C.; Barnett, J. Consumer acceptance of cultured meat: A systematic review. Meat Sci. 2018, 143, 8-17. [CrossRef] 
85. Bryant, C.J.; Anderson, J.E.; Asher, K.E.; Green, C.; Gasteratos, K. Strategies for overcoming aversion to unnaturalness: The case of clean meat. Meat Sci. 2019, 154, 37-45. [CrossRef]

86. Newman, L. The promise and peril of "culture meat". In Green Meat? Sustaining Eaters Animals and the Planet; Katz-Rosene, R.M., Martin, S.J., Eds.; McGill-Queen's Press-MQUP: Montreal, QC, USA, 2020; pp. 169-182.

87. Verhoog, H. The concept of intrinsic value and transgenic animals. J. Agric. Environ. Ethics 1992, 5, 147-160. [CrossRef] [PubMed]

88. Schicktanz, S. Ethical considerations of the human-animal-relationship under conditions of asymmetry and ambivalence. J. Agric. Environ. Ethics 2006, 19, 7-16. [CrossRef]

89. Rollin, B.E. On telos and genetic engineering. In Animal Biotechnology and Ethics; Holland, A., Johnson, A., Eds.; Springer: Boston, MA, USA, 1998; pp. 156-171.

90. Ishii, T. Genome-edited livestock: Ethics and social acceptance. Anim. Front. 2017, 7, 24-32. [CrossRef]

91. Kramer, K.; Meijboom, F.L.B. Using Breeding Technologies to Improve Farm Animal Welfare: What is the Ethical Relevance of Telos? J. Agric. Environ. Ethics 2021. [CrossRef]

92. Fraser, D. Animal Welfare and the intensification of animal production. In Ethics of Intensification: Agricultural Development and Cultural Change; Thompson, P.B., Ed.; International Library of Environmental, Agricultural and Food Ethics; FAO: Rome, Italy, 2008; Volume 16, pp. 167-189.

93. Van Eenennaam, A.L. Application of genome editing in farm animals: Cattle. Transgenic Res. 2019, 28, 93-100. [CrossRef]

94. Pryce, J.E.; Haile-Mariam, M. Symposium review: Genomic selection for reducing environmental impact and adapting to climate change. J. Dairy Sci. 2020, 103, 5366-5375. [CrossRef]

95. Sonstegard, T.; Carlson, D.; Lancto, C.; Fahrenkrug, S. Precision animal breeding as a sustainable, non-gmo solution for improving animal production and welfare. Bienn. Conf. Aust. Soc. Anim. Prod. 2016, 31, 316-317.

96. Hötzel, M.J. Improving farm animal welfare: Is evolution or revolution needed in production systems? In Dilemmas in Animal Welfare; Appleby, M.C., Weary, D.M., Sandoe, P., Eds.; CABI: Oxfordshire, UK, 2014; pp. 67-84.

97. De Graeff, N.; Jongsma, K.R.; Johnston, J.; Hartley, S.; Bredenoord, A.L. The ethics of genome editing in non-human animals: A systematic review of reasons reported in the academic literature. Philos. Trans. R. Soc. B 2019, 374, 20180106. [CrossRef] [PubMed]

98. Guivant, J.S.; Macnaghten, P. Breaking the consensus: A perspective on technological governance from Brazil. In Quantum Engagements: Social Reflections of Nanoscience and Emerging Technologies; Zülsdorf, T.B., Ed.; IOS Press pp: Heidelberg, Germany; AKA Verlag: Heidelberg, Germany, 2011; pp. 109-122.

99. Capalbo, D.M.F.; Arantes, O.M.N.; Maia, A.G.; Borges, I.C.; da Silveira, J.M.F.J. A study of stakeholder views to shape a communication strategy for GMO in Brazil. Front. Bioeng. Biotech. 2015, 3, 179. [CrossRef] [PubMed]

100. Guivant, J.S.; Macnaghten, P. An analysis of the GM crop debate in Brazil. In Governing Agricultural Sustainability: Global Lessons from GM Crops; Macnaghten, P., Susana, C.R., Eds.; Routledge: London, UK, 2015; pp. 74-104. 